University of Michigan Law School University of Michigan Law School Scholarship Repository

2000

\title{
Lilly v. Virginia Glimmers of Hope for the Confrontation Clause?
}

Richard D. Friedman

University of Michigan Law School, rdfrdman@umich.edu

Available at: https://repository.law.umich.edu/articles/599

Follow this and additional works at: https://repository.law.umich.edu/articles

Part of the Constitutional Law Commons, Criminal Procedure Commons, Evidence Commons, and the Supreme Court of the United States Commons

\section{Recommended Citation}

Friedman, Richard D. "Lilly v. Virginia Glimmers of Hope for the Confrontation Clause?" Int'l Comment. on Evidence 1, no. 2 (2000). The final publication is available at www.degruyter.com at http://dx.doi.org/10.2202/1554-4567.1006.

This Article is brought to you for free and open access by the Faculty Scholarship at University of Michigan Law School Scholarship Repository. It has been accepted for inclusion in Articles by an authorized administrator of University of Michigan Law School Scholarship Repository. For more information, please contact mlaw.repository@umich.edu. 


\section{International Commentary on Evidence}

Volume 1, Issue 2

2000

Article 6

A General Collection of Works Prior to 2004

\section{Lilly v. Virginia Glimmers of Hope for the Confrontation Clause?}

Richard D. Friedman, University of Michigan Law School

Recommended Citation:

Friedman, Richard D. (2000) "Lilly v. Virginia Glimmers of Hope for the Confrontation Clause?," International Commentary on Evidence: Vol. 1 : Iss. 2, Article 6.

DOI: $10.2202 / 1554-4567.1006$

(C)2000 by the authors. All rights reserved. 
In 1662, in The Case of Thomas Tong and Others, [1] which involved charges of treason against several defendants, the judges of the King's Bench conferred on a crucial set of points of procedure. As reported by one of the judges, Sir John Kelyng, the judges agreed unanimously that a pretrial confession made to the authorities was evidence against the Party himself who made the Confession, and indeed, if adequately proved could support a conviction of that party without additional witnesses to the treason itself. But -- again unanimously, and quite definitively -- the judges also agreed that the confession cannot be made use of as evidence against any others whom on his Examination he confessed to be in the Treason. [2]

In 1791, the United States of America amended its new Constitution to provide, also in rather simple terms, that in all criminal prosecutions, the accused shall enjoy the right ... to be confronted with the witnesses against him. [3] In 1999, the United States Supreme Court faced another capital case, this one for murder, in Lilly v. Virginia. [4] The critical evidence in Lilly was an accomplice's pretrial confession to the authorities: [5] One Mark Lilly had given a statement to the police in which he identified his brother Benjamin, the defendant, as the triggerman in the murder, which was part of a crime spree in which both brothers and a third man had participated. Although Mark did not testify at Benjamin's trial, the trial court admitted his pretrial statement, and Benjamin was convicted. The Virginia Supreme Court upheld the conviction. The United States Supreme Court was split on admissibility of Mark's statement. Four Justices B the Chief Justice joined by Justices O'Connor and Kennedy and, in substantial part, by Justice Thomas B were not satisfied that the Virginia courts had acted properly in allowing Mark's statement into evidence, but were also not sure that those courts had violated Benjamin's confrontation right. They would have remanded the case to the Virginia courts for a more detailed analysis of the facts. [6] Five Justices, however, concluded that admitting the confession violated Benjamin's rights. A plurality of four, in an opinion by Justice Stevens, reached this result only after an extensive analysis, in accordance with prevailing confrontation doctrine, of the reliability of the statement. One of the four, Justice Breyer, raised serious doubts about that doctrine, however, and emphasized that the door was open for a much different approach to confrontation. Only Justice Scalia, who had joined an earlier attempt by Justice Thomas to reconceptualize confrontation theory, saw the case in simple, Tong-like terms, characterizing the admission of Mark's statement in a one-paragraph opinion as a paradigmatic Confrontation Clause violation." [7]

This is not, in my view, a happy story of the progress of human liberty over the last three and a half centuries. I believe the Tong court had a clearer conception of what the confrontation right means - and meant even then, long before the Sixth Amendment to the Constitution expressed it - than does most of the current Court. The right, one of the great glories of the Anglo-American system of 
adjudication, expresses the conditions under which testimonial statements must be given if they are to be acceptable proof against a criminal defendant. Recent Supreme Court doctrine has so deeply enshrouded the right in the mysteries of hearsay law that it has been all but lost. But Lilly also gives reason for hope, for Justices Scalia, Breyer, and Thomas have indicated that they are willing to think anew about what the confrontation right means and how it should be applied. [8]

In the first portion of this brief essay I will discuss Lilly against the backdrop of prevailing confrontation doctrine. I will focus on the opinions of Justices Stevens and Chief Justice Rehnquist, which purported to apply this doctrine, and I will argue that it is inadequate. In the second part of the essay, I will argue that the opinions of Justices Breyer and Scalia point the way to a sounder conception of the confrontation right: Lilly was as clear-cut as Justice Scalia made it seem, [9] as becomes apparent under the type of approach for which Justice Breyer indicated sympathy. My own preference for such an approach will not surprise anyone familiar with the amicus brief, cited by Justice Breyer, that two co-authors and I submitted on behalf of the American Civil Liberties Union.

\section{I.}

Under prevailing doctrine, the key question applying the Confrontation Clause to an out-of-court statements is whether the statement is reliable. [10] Following Ohio v. Roberts [11], the courts first must determine whether the statement fits within a firmly rooted hearsay exception and, if it does not, whether there are sufficient particularized guarantees of trustworthiness to warrant admissibility notwithstanding the lack of confrontation.

In affirming Benjamin Lilly's conviction, the Virginia Supreme Court held that Mark's statements fit within the Commonwealth's hearsay exception for statements made against the penal interest of the declarant. Federal Rule of Evidence 804(b)(3) includes an exception for some declarations against penal interest, as does the evidentiary law of most states. Nevertheless, in the two lead opinions in the United States Supreme Court, Justice Stevens and the Chief Justice each repeated the Court's pronouncement in Lee v. Illinois that the simple categorization of a statement as a 'declaration against penal interest' . . defines too large a class for meaningful Confrontation Clause analysis. [12] As in Lee, that statement is a remarkable confession of difficulty. Roberts had said that the reliability requirement could be satisfied without more if a statement fits within a firmly rooted hearsay exception. The Lee statement appears to say, in essence, that even if most American jurisdictions articulate an exception in concise terms as is true with respect to the exception for statements against penal interest and all the other exceptions listed in Federal Rules of Evidence 803 and 804 - the Court might decide to dissect the exception, deeming the Roberts reliability requirement to be satisfied "without more" by some, but not all, sub-categories of statements 
that some courts have deemed to be within the exception. Though Roberts aimed at simplifying the law, its rubric thus ultimately requires the courts to resolve two difficult questions as a matter of federal constitutional law: Within what bounds, if any, should the given exception be considered firmly rooted? Do the particular statements at issue fit within those bounds?

Chief Justice Rehnquist focused on the second of these issues. He believed that the portions of Mark's statements against his penal interest were so far removed in time and place from the statements pointing to Benjamin as the triggerman that the latter simply could not be considered as declarations against penal interest for Confrontation Clause purposes. Thus, he concluded that there was no need for the Court to make a categorical pronouncement denying the possibility that some statements that inculpate both the declarant and the defendant might be considered to be within a firmly rooted exception. [13] On behalf of the plurality, however, Justice Stevens did make such a pronouncement, for he focused on the first of the questions. After a long exegesis on the exception for statements against penal interest, he declared that accomplices' confessions that inculpate a criminal defendant are not within a firmly rooted exception to the rule against hearsay as that concept has been defined in our Confrontation Clause jurisprudence. [14]

That was not the end of the matter, however. Under prevailing doctrine, the statements might still have satisfied the reliability requirement of Roberts if they were supported by sufficient particularized guarantees of trustworthiness. In applying state hearsay law, the Virginia Supreme Court concluded that the statements were reliable in the context of the facts and circumstances under which [they were] given. [15] The plurality in the Supreme Court, however, refused B over the protest of the Rehnquist group B to hold that appellate courts should defer to lower courts' determinations regarding whether a hearsay statement has particularized guarantees of trustworthiness. [16] Though they recognized that the matter was a fact-intensive one, they believed that independent review was necessary to clarify and control application of the principles underlying the constitutional protection. [17] Justice Stevens therefore embarked on a factintensive review to determine whether Mark Lilly's statements were supported by sufficient particularized guarantees of trustworthiness, and he concluded that they were not.

In accordance with Idaho $v$. Wright, the plurality confined its inquiry concerning indicia of the statements' reliability to those that indicated their inherent reliability. [18] Inherent reliability sounds like a rather metaphysical standard, but it is clearly meant to prevent the courts from using corroborative evidence to support conclusions about reliability B despite the fact, well articulated by Justice Kennedy in dissent in Wright, that it is a matter of common sense for most people that one of the best ways to determine whether what someone says is trustworthy is to see if it is corroborated by other evidence. [19] In that light, the Court's 
reason for excluding corroboration from the inquiry must remain, to some extent, a matter of speculation. Two partial explanations seem fairly plausible: First, if courts could rely on corroboration, the test would essentially be whether the court believed the statement, which in many cases would be essentially whether the court believes the defendant to be guilty. Second, requiring courts to base their conclusions on corroborative evidence would make the inquiry even more intensely fact-dependent. [20]

Under the Roberts rubric, then, Lilly was a rather difficult case. First, the Court had to compare the statements at issue to a hearsay exception, deciding whether the statements fit within whatever portion of the exception the Court would deem to be firmly rooted for purposes of the Confrontation Clause. Once the plurality [21] and the Chief Justice's group concluded that the statements did not fit such a category, [22] , they had to determine whether the statement was supported by sufficient particularized guarantees of trustworthiness to overcome the lack of confrontation B but in making that judgment, they were precluded from relying on a source of information, corroborative evidence, to which one would normally look in assessing trustworthiness.

The difficulty, in my opinion, is that the Court has perceived the confrontation right as primarily a means of guaranteeing the trustworthiness of evidence. It is difficult to make any useful generalizations about trustworthiness because it depends so much on the facts of the particular case. The Court has, accordingly, been caught between two alternatives: first, relying on the common exceptions to the rule against hearsay for broad generalizations about trustworthiness that are not particularly useful or at least not particularly dependable, and, second, deciding each case on its facts. Neither technique is satisfactory in itself, and the Court has chosen to use each to some extent. [23] The result is that, in addition to other problems, Confrontation Clause jurisprudence becomes quite complex. [24]

\section{II.}

Should Lilly have been so difficult? Justice Scalia's brief opinion suggests that it should not have been, and that both Justice Stevens and Chief Justice Rehnquist overlooked some basic principle that should have made the case easy:

During a custodial interrogation, Mark Lilly told police officers that petitioner committed the charged murder. The prosecution introduced a tape recording of these statements at trial without making Mark available for cross-examination. In my view, that is a paradigmatic Confrontation Clause violation. ... Since the violation is clear, the case need be remanded only for a harmless-error determination. [25] 
Justice Scalia did not attempt to articulate a guiding principle, however. Ironically, though Justice Stevens' opinion adhered to the reliability-based orthodoxy and refused to speak in categorical terms, it did point towards glimmerings of such a principle:

It is highly unlikely that the presumptive unreliability that attaches to accomplices' confessions that shift or spread blame can be effectively rebutted when the statements are given under conditions that implicate the core concerns of the old ex parte affidavit practice B that is, when the government is involved in the statements' production, and when the statements describe past events and have not been subjected to adversarial testing. [26]

Although he joined the plurality opinion, Justice Breyer wrote separately to suggest that Confrontation Clause jurisprudence might be improved by severing its link to hearsay doctrine and recognizing that the Clause was principally meant to protect the right of an accused to meet his accusers face to face rather than the trustworthiness of evidence. [27] I agree. And if the full Court accepts this principle, we will have come a long way towards understanding the confrontation right.

The confrontation right expresses the insistence of the Anglo-American system that testimony be given under oath, face-to-face with the adverse party, and, if feasible, in open court. Not all systems require that testimony be given in this manner. In later ancient Greek procedure, for example, witnesses testified in writing. Medieval continental systems took testimony out of the presence of the parties. [28] Indeed, although the open and confrontational style of giving testimony has been characteristic of English trials for more than half a millennium, the accused's right to insist on it was often assaulted until the middle of the seventeenth century. The case of Walter Raleigh is the most notorious prosecution, but not the only one, in which defendants pleaded unsuccessfully that their accusers should be brought face to face with them.

In this light, I think we can see what the Confrontation Clause is all about: It is not a generalized rule against hearsay, subject to exceptions. Rather, it is a structural rule meant to ensure that a witness against an accused testifies only in the manner approved by the common law system B under oath and in the presence of the accused, so that the accused may examine her. The Clause covers not all hearsay declarants, but only witnesses $B$ those who give testimony.

But what does testimony mean? I will postpone an answer briefly by making one preliminary note: An out-of-court statement may be testimonial, even if it is made informally, not under oath. The informality does not make the statement nontestimonial. Rather, it only means that the statement is not acceptable testimony. 
The whole point of the Clause is to ensure that testimony be given under appropriate conditions. If a statement is genuinely testimonial, the absence of one of those conditions $B$ for example, the oath B does not mean that the Clause does not apply and therefore that other conditions $B$ particularly cross-examination $B$ need not be satisfied.

So, what makes a statement genuinely testimonial for analysis of the confrontation right? A precise definition is not easy, but I think the basic idea is this: If the circumstances are such that a reasonable person would realize that the statement will likely be used in investigation or prosecution of a crime, then the statement is testimonial. No matter how informal the context of the statement may be, if the speaker makes it understanding that it will be used against a criminal defendant, she is acting as a witness against the defendant. Any system that admits such a statement thereby tolerates informal means of testimony, which the Confrontation Clause is meant to preclude.

I do not pretend that all cases will be easy under this approach. With respect to some statements made to a private listener, for example, there may be a close question as to whether a reasonable person in the declarant's position would anticipate that the listener would pass the statement on to the police. But a test is not bad simply because it yields hard cases; sometimes the right question leads to a difficult answer. Moreover, this test shows why a case like Lilly is not hard. Mark Lilly was speaking directly to the authorities, who he knew were investigating a murder. He also knew that the authorities understood him to be in a position to offer information on the murder $\mathrm{B}$ and he did just that by identifying the triggerman. Obviously, he was in a position to understand that this information was of investigative interest to the police and that, if the system allowed, his statement could be used at trial. When his statement was admitted at trial, therefore, it meant that Mark Lilly had testified against a criminal defendant by making a statement to the police, neither under oath nor subject to crossexamination. And this the Confrontation Clause clearly prohibits.

The Confrontation Clause should not be viewed as a flabby doctrine applicable to all hearsay but excluding only that portion of it perceived to be trustworthy. Rather, the Clause reflects a narrow but categorical rule: Anyone who testifies against an accused must do so in the way demanded for centuries by the common law system of criminal justice, openly, in the presence of the accused, under oath, and subject to adverse examination. This right is subject to forfeiture. For example, the accused cannot complain about his inability to cross-examine the witness at trial if he has rendered her unable to testify there, say by killing her. [29] But apart from that narrow qualification, the right should be regarded as absolute, still one of the pillars of our system. 


\section{Endnotes}

* Ralph W. Aigler Professor of Law, University of Michigan Law School. Many thanks to Craig Callen for numerous valuable suggestions and to Frank Herrmann for steering me straight on medieval procedures.

[1] 84 Eng. Rep. 1061 (1662).

[2] 84 Eng. Rep at 1062.

[3] U.S. Const. amend VI.

[4] 527 U.S. $116(1999)$.

[5] Id. at 121.

[6] Id. at 148 (Rehnquist, C.J., concurring).

[7] Id. at 143. (Scalia, J., concurring).

[8] See Comment, Confrontation Clause B "Firmly Rooted" Hearsay Exceptions, 113 HARV. L. Rev., 233, 243-44 (1999) (saying that Lilly "should prompt the sort of reevaluation of the Court's hearsay-based Confrontation Clause jurisprudence that Justice Breyer imagined in his concurrence").

[9] Lilly, 527 U.S. at 143 (Scalia, J., concurring).

[10] In some circumstances, the prosecution is also required to show that the declarant is unavailable. In recent cases, the Court has generally minimized the importance of unavailability. In Lilly, it put the issue aside by assuming that, because he was asserting the privilege against self-incrimination, Mark Lilly was unavailable. I will make the same assumption. I will also put aside the possibility $B$ because it is not one that the courts addressed B that Mark asserted the privilege because of persuasion or inducement by Benjamin or someone acting in his interests.

[11] 448 U.S. 56 (1980).

[12] Lilly, 527 U.S. at 127 (plurality opinion)(quoting Lee v. Illinois, 476 U.S. 530, 544 n.5 (1986); id.. at 145 (Rehnquist, C.J., concurring).

[13] Id. at 146.

[14] Id. at 134 (plurality opinion).. 
[15] 255 Va. 558, 574, 499 S.E.2d 522, 534 (1998). Because the Virginia court had drawn this conclusion in the context of state hearsay law rather than the particularized guarantees test under the Confrontation Clause, four Justices B the Rehnquist group of three, see Lilly, 527 U.S. at 148, and apparently also Justice Thomas, $i d$. at $148 \mathrm{~B}$ would have remanded for a determination under that test. Justice Stevens concluded that a remand was unnecessary. Id. at 135 n.6.

[16] Lilly, 527 U.S. at 136.

[17] Id..

[18] 497 U.S. 805, 822 (1990).

[19] Id. at 828 .

[20] See Richard D. Friedman, The Elements of Evidence 326 (2d ed. 1998).

[21] Lilly, 527 U.S. at 134.

[22] Id.. at 145 (Rehnquist, C.J., concurring.).

[23] For example, in White v. Illinois, 502 U.S. 346 (1992), the Court relied on the very dubious psychological generalizations underlying the spontaneous declaration and medical statement exceptions to hold that the Confrontation Clause was not violated. In other cases, including Lee and Idaho v. Wright, as well as Lilly, the justices, having not found the statements to fit within a firmly rooted exception, have engaged in a case-specific determination of trustworthiness.

[24] For a fuller exploration of the inadequacy of trustworthiness as the touchstone for Confrontation Clause analysis, see Richard D. Friedman, Confrontation: The Search for Basic Principles, 86 Georgetown L.J. 1011, 102729 (1998). I also believe that trustworthiness is a poor criterion in general for determining the admissibility of hearsay. See Richard D. Friedman, Truth and Its Rivals in the Law of Hearsay and Confrontation, 49 Hastings L.J. 545, 552-56 (1998).

[25] Lilly, 527 U.S. at 143 (Scalia, J., concurring in part and concurring in the judgment).

[26] Id. at 137 (plurality opinion).

[27] Id. at 140. 
[28] Frank R. Herrmann \& Brownlow Speer, Facing the Accuser: Ancient \& Medieval Precursors of the Confrontation Clause, 34 Va. J. Int'1 L. 481, 515-16 (1994). Under these systems, however, the parties did have the right to be present when the witnesses were sworn. Id. at 518-19.

[29] I explore the issues related to forfeiture in Confrontation and the Definition of Chutzpa, 31 Israel L. Rev. 506 (1997). 